\title{
The Potential of the Human Soul towards a Life in Harmony with Nature and Logos as Per the Stoic Psychology
}

\author{
Spyridoula G. Kostara \\ Department of Pastoral Studies, Supreme Ecclesiastical Academy of Athens, Athens, Greece \\ Email: spykostara@gmail.com
}

How to cite this paper: Kostara, S. G. (2021). The Potential of the Human Soul towards a Life in Harmony with Nature and Logos as Per the Stoic Psychology. Psychology, 12, 1246-1258.

https://doi.org/10.4236/psych.2021.128078

Received: July 16, 2021

Accepted: August 10, 2021

Published: August 13, 2021

Copyright $\odot 2021$ by author(s) and Scientific Research Publishing Inc. This work is licensed under the Creative Commons Attribution International License (CC BY 4.0).

http://creativecommons.org/licenses/by/4.0/

\section{(c) (i) Open Access}

\begin{abstract}
The aim of this paper is the approach of the fundamental principles and concepts of the Stoics' theory on humans and the soul, as well as the designation of the scientific solidity and impact this theory exerts on the psychological research, establishing the full harmonisation between the behaviour and acts of mankind and the natural development of facts as the purpose of human existence. In particular, the role of cognition, of sensation and experience, the role of impulse and familiarity, the power of reason, what passion is and its impact on mental life are some of the key issues of the Stoics' psychological theory which this paper endeavours to address, primarily employing the Hermeneutics methodology, that of text interpretation. It considers of primary importance to provide an in-depth interpretation of the Stoics' "Fragments" and reveal their essence and real meaning, without, of course, underestimating the importance of secondary literature.
\end{abstract}

\section{Keywords}

Stoic Psychology, Experience, Sensation, Impulse, Cognition, Familiarity, Passion

\section{Introduction}

The position of Platonic and Aristotelian philosophy took on unilateral subjective systems at the time of Alexander the Great. Individuals were emancipated from the state and society and Philosophy was placed at the service of the subject. It was this that would give them what the deteriorating religiousness and morality were no longer able to offer them: a single, solid in life and in practice world-view (Krämer, 1971). It was up to Philosophy now to explain everything; 
so it became dogmatic and, given it was only interested in the truth of the individual as a subject, it proved unilateral. Consequently, Scepticism emerged vis-a-vis Dogmatism (Graeser, 1975; Sandbach, 1975).

The main philosophical system of the Hellenistic period was Stoicism. The founder of the Stoic School was Zeno (335-263 BC). He was born in Citium, Cyprus, and died in Athens. A student of Crates of Cynic, Stilpo of Megara, and Xenocrates and Polemo of the Academy, he demonstrated exemplary dedication to his studies as well as rare philosophical maturity. His school was named after the Stoa Poikile. Zeno's successors as Scholarchs of the Stoic School were: Cleanthes (304-233 BC) from Assos in the Troad, Chrysippus (281-208 BC) from Soli, Cilicia, Zeno (of the 2nd century BC) from Tarsus, Panaetius (180-109) from Rhodes, Posidonius (135-51 BC) from Apamea, Syria, Seneca (4 BC-65 AD), Gaius Musonius Rufus, Epictetus (50-138 AD) from Hierapolis, Hierocles, Marcus Aurelius (121-180 AD) and Cebes, the last Stoic (Rist, 1969).

The Stoics used a simile for Philosophy, comparing it to a garden, where Logic was the fence, Physics, the trees and Ethics, the fruit. Therefore, Ethics carried the weight. They asserted that the only thing of value in life was the pursuit of wisdom, meaning the knowledge of divine and human matters.

Logic teaches the method used to reach true knowledge; Physics encompasses the teachings about nature and the order of the Universe; Ethics extracts conclusions on the ways of life (Schink, 1913).

Stoicism has exercised a considerable influence for centuries with its marvellous cohesion and magnificent themes, as it has urged individuals to follow a life consistent with nature and logos, and identified the absolute harmony between an individual's behaviour and actions and the true, i.e. the natural, turn of events as the purpose of human existence. Psychology, as an integral part of natural Philosophy, is closely linked to this purpose (Forschner, 1981).

This paper aims to illustrate both the scientific solidity and remarkable resilience over time of the Stoics' theory about humans and the soul, and its impact up to these days: to perceive man as a single yet not a uniform substance, and knowledge as arising from the unified action of cognition and sensation (aesthesis). Contemporary psychology, despite its indisputable progress, never diverged from the Stoics' frame of mind, and never ceased to adopt its fundamental concepts and terminology: hegemonikon, sensory perception, impulse, familiarity etc. This paper employs mostly the hermeneutics methodology, that of text interpretation. It considers fundamental to provide a deep interpretation of the "Fragments" of the Stoics and reveal their essence and real meaning, without underestimating the importance of secondary literature. What is more, it aspires to trigger further reflection and scientific interest.

\section{Fundamental Principles, Concepts and Influences of the Stoic Psychology}

\subsection{Sensory Perception, Thought and Knowledge}

The teachings regarding the soul are the key to understanding and interpreting 
Stoicism. Strength and the nature of the soul, according to Panaetius, are two-fold: the one part is impulse (horme), which drives individuals to one or the other direction, and the other is the rational part, which dictates and explains what one has to do and what they must avoid (Cicero, ca. 45 BCE/1994; Fritz, 1972). Man is a single yet not a uniform substance. A distinction may be made between physical composition, flesh, muscles and blood, and the ability to feel, speak and think. Basically, it is the traditional distinction between body/soul or substance/spirit (pneuma), with the essential difference being that the spirit penetrates and saturates the substance (Long, 1982).

This means that knowledge arises from the unified action of thought, which cannot perceive anything on its own, and sensation, which again cannot think on its own (Gourinat, 2012). Therefore, thought has no a priori content. The mind at birth is a "tabula rasa" and "paper ready for writing upon" (Arnim, 1903-1905/1964a; Plutarch, ca. 90 AD/1925a). The soul resembles a sheet of paper, finely processed to record impressions. These impressions appear in the mind after external objects or events act on the sensory organs; so the first recording process is the result of sensory perception. If the impression is kataleptic (cognitive), according to the Stoic vocabulary, its appearance constitutes true perception, consciousness of an event that is real. Put simply:

Each piece of knowledge stems from a sensory perception, from the object, the environment; not from the subject, the individual. In tune with Aristotle, the Stoics believed sensation (aesthesis) to be a condition for the function of the soul, since nothing "is possible without sensation" (Aristotle, ca. 350 BCE/1956). For without sensation, it is impossible for the soul to exercise its perceptive strength and creative energy. Because "nor does reason apprehend objects in space, except when it acts in conjunction with sense-perception" (Aristotle, ca. $350 \mathrm{BCE} / 1955)$. The translation of this excerpt has become some sort of a rule in global psychological research: "Nihil est in intellectu, quod non prius fuerit in sensu, Nothing is in the intellect that was not first in the senses."

Based on their view that without the feeding effect of the impacts and impressions of the outside world, the soul is empty, the Stoics became proponents of the Psychophysical theory, which introduces the mechanics prevalent in the physical world to the mental arena, meaning that the universal law of cause and effect also applies for the mental sphere ${ }^{1}$ : an external stimulus produces an internal reaction. So the soul is a bundle of reactions, reflections and external influences. Given that it is possible to measure the magnitude of the influence, accordingly it is possible to measure the magnitude of the reaction.

This theory of the Stoics went through multiple renderings, scientific admixtures and transformations and demonstrated remarkable resilience over time (Stein, 1886; Robertson, 2016). For example: in the more modern era, the theory

${ }^{1}$ On the law of causality: the human mind has the dual ability of 1) recognising events and 2) viewing them in relation to cause and effect: everything is the result of something that happened before and the reason for something that happens next. This ability of the mind to place events in a causal relation between them is called category of causality and the fact that everything falls under this law is described as causation. 
of Psychophysics was adopted by British empiricists, such as J. Locke (1632-1704), who described the soul as tabula rasa (direct translation of the Stoics' terms). The French philosopher Condillac (1715-1780), who, being an avid supporter of Sensualism, attributed full value to the senses, since he considered them to be the exclusive source of knowledge, while man was just an inactive statue, animated by sensory influences. Russian physiologists/psychologists Ivan Pavlov (1849-1936) and Vladimir Bekhterev (1857-1927) with the Theory of conditioned and acquired reflexes, also known as the theory of Signals. American philosophers and psychologists W. James (1842-1910), J. Dewey (1859-1952), J. Watson (1878-1958), Ed. Thorndike (1874-1949) and G. Mead (1863-1931) with Behavioural Psychology as an evolved form of Sensualism and the theory of Psychophysics. Propaganda psychologists, who not only believe in the physical, but also the social environment, meaning that the controlled external events can give rise to a certain type of person. Further research on the influence of Stoic thought in modern Neuropsychology, which engages in the interconnection of neurological processes and behavior, as well as the cognitive behavioural therapy, a widely used practice for the improvement of mental health, is of distinct and particular interest.

\subsection{Experience and Cognitive Certainty}

The scientific resilience of the Stoics' theory of Psychophysics through the centuries is a testament to its validity (Striker, 1974). According to them, experience, as a criterion of truth, is the only thing that can produce cognitive certainty: Out of the eight parts, the eight qualities or powers of the soul - meaning 1) the five senses, 2) the reproductive process, 3 ) the ability of speech - it is the eighth power, the hegemonikon, that "is able to govern" (Arnim, 1903-1905/1964b; Gourinat, 1999). The hegemonikon "is the dominant part of the soul, which is its most excellent part” (Diogenes Laërtius, ca. 222-235 AD/1999a). It functions not just by simply recording impressions, but by classifying, distinguishing, judging and interpreting them. However, the hegemonikon, as the superior rational principle, functions thanks to the reserve of concepts it has accumulated through experience. So, according to A.A. Long, the existence or truth of things is not established through logic, but through the empirical criterion of "cognitive impression" (Long, 1986).

\subsection{Impulse and Familiarity}

The energy of the soul's hegemonikon is impulse, as an innate command that motivates one to act: "the reason of a man commanding him to do something" (Arnim, 1903-1905/1964c; Diogenes Laërtius, ca. 222-235 AD/1999b; Plutarch, ca. $90 \mathrm{AD} / 1925 \mathrm{~b}$ ) or as "movement of the soul towards something" or "action to remove the soul from something" (Arnim, 1903-1905/1964d; Diogenes Laërtius, ca. 222-235 AD/1999c).

To this end, consent, as a necessary condition for impulse, understanding and familiarity stem from the hegemonikon of the soul and are considered by the 
Stoics as determining factors of human behaviour. Familiarity in particular not only determines the relationship with the environment, but also the relationship of man with himself, since the self is who we are primarily familiar with (Diogenes Laërtius, ca. 222-235 AD/1999d).

Familiarity and intimacy do not necessarily mean closeness, being close, but direct interaction with ourselves and the entities we meet. So, we follow the ultimate rule as per the Stoics, "living agreeably to nature" (Stobaeus, ca. 5th century AD/1884-1912). This implies 1) the psychological need to connect to and get to know ourselves and the world and 2) the purpose of evolving towards a life agreeable to the rational human existence, harmonised as to the processes of the universal nature.

\subsection{The Sensation as a Complex Mental Phenomenon}

True to their entire theoretical approaches and their empirical orientation, the Stoics built their teachings about the soul on these foundations, strongly underlining the major importance of the sense and sensation for the mental life of an individual. Modern Psychology owes them much; above all, the clear distinction between stimulation (physical event), stimulus (normal event) and feeling (representational/cognitive event).

More precisely, the Stoics perceived feeling as a main way of life and function of the hegemonikon and the spirit, and sensation as a complex mental phenomenon, which encompasses familiarity, understanding, concurrence and consent. On this subject Aetius, a famous doxographer of the 2nd century AD, in his work Opinions of the Philosophers Synagogue wrote: "The Stoics define aesthesis (sensation) in the following manner: 1) aesthesis is an apprehension or cognition through an aestheterion (sensory organ). And aesthesis has several meanings: it refers to 2) the ability and 3) the function and 4) its result. Moreover, the cognitive presentation is produced in the commanding faculty by means of an aestheterion. On account of this, 5) aestheteria to intelligent breath stretching from the commanding faculty of the organs" (Arnim, 1903-1905/1964e). In simpler words, the presentation or the perceptibility of concepts forms in the area of hegemonikon with the aid of some stimulus. And this is what gives the name (5) aestheteria to the mental breath, "mental spirits", which stretch from the hegemonikon to the organs.

About a century later, the prominent biographer, doxographer and philosopher Diogenes Laërtius captured in much the same way the names and multiple meanings of sensation in his work Lives and Opinions of Eminent Philosophers (books ten); "The Stoics apply the term sense or sensation (ailo $\theta \eta \sigma \iota)$ to: 1) the current passing from the principal part of the soul to the senses, 2) apprehension by means of the senses, 3) the apparatus of the sense-organs, in which some persons are deficient. Moreover, 4) the activity of the sense-organs is itself also called sensation [...]" (Arnim, 1903-1905/1964f; Diogenes Laërtius, ca. 222-235 AD/1999e; Diogenes Laërtius, ca. 222-235 AD/1828). 
The objects of sensation are the sensibles; everything that falls under the senses: the tangible, the extendable. Both existent and non-existent objects can belong to the sensibles. The sensation that refers to existent objects is true; when it refers to non-existent, it is false: "And the Stoics [...] have said that some sensibles really exist, as being true, and some do not exist, as sensation lies about them: some of the objects of the senses do exist, to te degree that they are real, then some others do not exists, but the sense we form about them is false," noted Sextus Empiricus, the physician and philosopher from Alexandria, in Against the Mathematicians (c. 200-250 AD) (Arnim, 1903-1905/1964g)2. In his Academica, Cicero (106-43 BC) "Quod autem erat sensu comprehensum, id ipsum sensum appelat: Anything perceived by one of the senses, he [Zeno] would also name it sensation" (Arnim, 1903-1905/1964h; Cicero, ca. 45 BCE/1970).

For sensation to work, it absorbs the object, extracts its properties and passes them on to the hegemonikon. However, "for a sensation to be caused, each sense organ must undergo an alteration; and an alteration is not imposed on any sense organ by any sensible, but by the relative that is affected by the colours from the radiance and the light, the relative that is affected by the voices from the wind, the relative that is affected by everything that produces smells through the vapours; in one word, the like are recognised by the like" (Arnim, 1903-1905/1964i; Diels \& Kranz, 1952). "The objects of sensations are complex bodies and the various sensations each sense something: one senses the colours, the other the sounds, the other the flavours of juices, the other the rough to the touch and the smooth" (Arnim, 1903-1905/1964j).

The importance in this case is that none of the senses can operate autonomously without receiving even the slightest nod from the hegemonikon. For example, for the sense of vision to act, the hegemonikon needs to emit an optic breath, which initially affects the pupil of the eye and then the air, which is in constant contact with it, "under the existent or optic spirit" (Arnim, 1903-1905/1964k).

The prominent representative of the Stoa, Chrysippus, after explaining that we have the ability to see thanks to brightness and also the intensity (tense motion) of the air, used the argument with the spider to clarify the relationship between hegemonikon and sensations, and their function: "As the spider in the middle of the web holds with its legs all the ends of the wires, and is able to immediately feel every bump of animals whatever be their origin; so the hegemonic of the soul perceives the first hints of activity of the senses and is immediately warned about what is going on" (Arnim, 1903-1905/1964l). Put simply:

The stimuli hit the sensors, which, just like the wires of the web, are captured by the hegemonikon and transmit to it the stimuli, stretched, creating the sensation, as the first and foremost cognitive phenomenon of the soul. The type of each sensation is determined by the smallest or largest tension that the hegemonikon provides to each tense motions, each breath (Arnim, 1903-1905/1964m; Diogenes Laërtius, ca. 222-235 AD/1999e).

${ }^{2}$ Outlines of Pyrrhonism is the other major work by Sextus Empiricus. 


\subsection{The Hegemonikon as the Rational Ruling Principle of the Soul}

To this end, the hegemonikon, which is the central concept of the system of the Stoics, is the source from which everything else takes up meaning and life (Annas, 1992); it is the logos of the soul that composes the world and guides everything else: it is the creative nature and the generating force, the eternal law, which acts within us. So everything happening in the world is determined by an endless correlation of causes, because the hegemonikon has the ability to arrange everything based on the relationship of cause and effect, and there is no interruption in this interconnected series: The World with its creatures is a ceaseless continuity. The hegemonikon is somewhat like the Directorate of the parts of the soul or the mental breath, and their vigilant coordinator. It is also called dianoia and nous (Arnim, 1903-1905/1964n). It is the rational ruling principle of the soul or breath, which saturates the entire body.

Chrysippus' excerpt about the soul is particularly interesting: "The soul is an innate breath inside us, continuous, overtaking the entire body, up to the point and time that the normal breath is present in the body" (Arnim, 1903-1905/19640). This excerpt by Chrysippus is extremely significant, as it clearly states that the Soul lays at the centre of the entire Stoic world view and the hegemonikon, the nous and the logos are at the centre of the soul. The human soul, contiguous to the logos, is part of the global Logos, just as Heraclitus taught. This Logos is the same as Logic, Nature, Fire, God or Fate. Therefore, as a part of this Logos, the human soul is charioted by the power of logos (Chiesa, 1991).

So, man, as a carrier of logos, can approach the truth and the order prevailing in the Universe and, depending on his strengths, contribute towards realising this universal order. However, the light of the logos, which lights up the human soul, meaning the presence of the rational element, automatically establishes the existence of the opposite of logos, the irrational, whose presence threatens to negate the axiom of the Stoics: the ability of man to approach the truth and work together to consolidate the universal order due to logos (Schubert, 1993).

Interpreting the axiom of the Stoics, Clement of Alexandria (c. 150-216), ecclesiastical writer and avid researcher of the Psychology of Stoicism, who proved a valuable and reliable source for Stoic theory, underlined that man can contribute to truth and order, but "in nothing influenced by the irrational part of his soul"3 (Clement, ca. 198-203 AD/1985). This includes: 1) the realisation that the irrational part of the soul exists and 2) the request for it to be subdued by the rational part of the soul - to revisit A. Lesky's interpretation (Lesky, 1957/2001).

\subsection{Passion as Detachment from Logos}

Therefore, anything that veers from logos is the passion of the soul (Ierodiakonou, 2015). That's why the iron syllogism of the Stoics defines passion (as per Diogenes Laërtius the first definition of passion was given by Zeno): 1) as the irrational motion of the soul, contrary to nature, distancing from normal measure, and 2) as ${ }^{3} \mathrm{cf}$. also the other two works by Clement: Protrepticus and Paedagogus. 
powerful thymoid derivatives, intense emotional states, which lead to actions en vrasmo psychis (in boiling soul = in a fit of rage) (Arnim, 1903-1905/1964p; Diogenes Laërtius, ca. 222-235 AD/1999f).

1) According to Themistius, Zeno's followers claimed that the passions of the soul are distortions of logic and erroneous judgements (Arnim, 1903-1905/1964q), while in his works On Passions, especially the first book, and Therapeutics, where he summarises his teachings on passions, Chrysippus underlines that passions are judgements and false beliefs; opinions and judgements of passivity, according to Cicero (Arnim, 1903-1905/1964r; Bréhier, 1951; Cicero, ca. 45 BCE/1998; Diogenes Laërtius, ca. 222-235 AD/1999g).

To this end, as per the Stoics, passion, according to Plutarch's testimony, is a rational expression, false and uncontrollable due to superficial and erroneous judgement, which took on increased tension and potency ${ }^{4}$ (Arnim, 1903-1905/1964s).

In his much-acclaimed work On the Doctrines of Hippocrates and Plato, Galen claims that, with regard to the definition of passion, there are fine differences in the views: "Chrysippus [...] tries to prove that the affections are certain judgements of the reasoning part. Zeno, however, held that the affections are not the actual judgements but the contractions and expansions, risings and fallings of the soul that supervene on judgements"5 (Arnim, 1903-1905/1964t; Galen, ca. $160 \mathrm{AD} / 1981)$. Conclusively, passions are irrational diseases of the hegemonikon (Sedley, 1993).

2) Apart from this first meaning, in Stoic Psychology, passions are defined as turbulent states of the soul (pertubationes animi), as per Cicero (Cicero, ca. 45 BCE/1998), which disrupt it, disturb the balance and deflect one's behaviour. The task of logos is to bring order to the unharnessed passion, when it fails to obey, when it does not follow its hegemon and when it violates its orders.

The Stoic Psychology is marked by a tendency to degrade and devalue the thymus, the ability to sympathise, a tendency that often leads to the perception that intense feelings have a harmful impact on mental life. Especially ambivalence and petulance. Ambivalence: in this case, a pair of opposing feelings appear together, such as joy and sadness, rage and fear, hatred and love, laughter and tears. The unparalleled writings of Homer describe such a turbulent mental state in Book 6 of the Iliad (lines 404-496), when Hector meets his wife

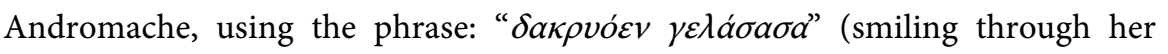
tears) (Kostara, 2013). Petulance: these are intense emotions, with uncontrollable, positive or negative, physical and mental consequences.

Stoic Psychology, from which Stoic Ethics largely stem from, is constantly concerned with harnessing the passions and feelings; however, no psychological research has ever been able to chart, name and define their diversity, shades,

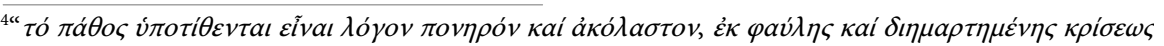

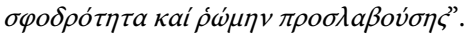

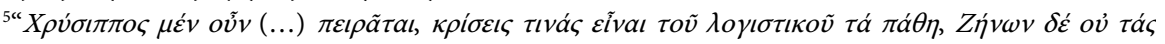

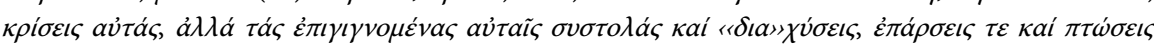

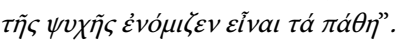


grades or wealth. There are countless 1) Organic feelings (pain, thirst, disgust, vomiting, saturation, tickling, sense of colours, sounds, tastes, smell, aphrodisiacs, drowning, hunger and so on); 2) Bodily feelings (stress, wellness/cachexia, overload/relaxation, vivacity/lethargy, indolence/mobility, vitality/exhaustion, health/sickness, youth/old age and so on); 3) Emotional feelings (joy, sadness, fear, rage, love, hatred, mournful despair, aversion, ultimate abandonment and so on); 4) Social feelings (contact, friendship, spiritual communication, mental unity, mimetic satisfaction, fondness/dislike, jealousy/envy, malevolence, creation, value recognition, dedication, submission and so on); 5) Intellectual/Ethical/Aesthetic/Metaphysical feelings (puzzlement, admiration, awe, mercy, enjoyment of beauty, dazzle, quietism, completion, revelation, sanctification and so on) (Becker-Carus, 2004). Faced by this inexhaustible wealth of the sentimental inner world, the great psychographer and poet Goethe recognised that "Gefühl ist alles" (emotion is everything) (Goethe, 1808).

The Stoics were completely aware of this emotional over-abundance. And with a deep and penetrating psychological view, they attempted to analyse many basic emotions (Brennan, 2005; Graver, 2007; Turner et al., 2021). Simply refer to On Passions by Zeno of Citium, founder of the Stoic school; the works On Emotions and Therapeutics by Chrysippus; Discourses by Epictetus; or Of Anger by Seneca. As Epictetus wrote: "It is this [passion] which introduces perturbations, tumults, misfortunes, and calamities; this is the spring of sorrow, lamentation, and envy; this renders us envious and emulous, and incapable of hearing reason" (Epictetus, ca. 104-107 AD/1916a).

Starting from this last excerpt by Epictetus, by way of conclusion, I mention two of the key axioms of Stoic Philosophy and Psychology: 1) Being aware of the sea of emotions, the purpose of man should be to withdraw the waters towards the solid continental land of logos, and 2) Philosophy and Psychology are pointless if they fail to liberate the soul and passion, just like Medicine is useless if it fails to rid the body of ailments (Porphyry, ca. 300 AD/1969).

At this point, let us listen carefully to the voice of the most distinguished representative of the modern Stoa, Epictetus (55-135 AD), who taught the following: "The philosopher's school, ye men, is a surgery." This lesson was inscribed on a sign over the entrance to the Library of Alexandria: "Surgery of the Soul" (Epictetus, ca. 104-107 AD/1916b; Long, 2002)!

\section{Conflicts of Interest}

The author declares no conflicts of interest regarding the publication of this paper.

\section{References}

Annas, J. (1992). Hellenistic Philosophy of Mind. University of California Press.

Aristotle (1955). Sense and Sensibilia. In D. Ross (Ed.), Parva Naturalia (pp. 71-102). Oxford University Press.

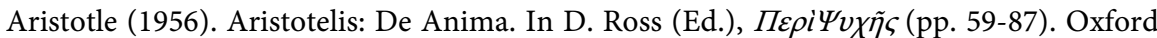


University Press.

Arnim, V. H. (1964a). Stoicorum Veterum Fragmenta (Vol. II, No. 83). Teubner. (Original Work Published 1903-1905).

Arnim, V. H. (1964b). Stoicorum Veterum Fragmenta (Vol. II, No. 827). Teubner. (Original Work Published 1903-1905).

Arnim, V. H. (1964c). Stoicorum Veterum Fragmenta (Vol. III, No. 171, 175). Teubner. (Original Work Published 1903-1905).

Arnim, V. H. (1964d). Stoicorum Veterum Fragmenta (Vol. III, No. 377). Teubner. (Original Work Published 1903-1905).

Arnim, V. H. (1964e). Stoicorum Veterum Fragmenta (Vol. II, No. 850). Teubner. (Original Work Published 1903-1905).

Arnim, V. H. (1964f). Stoicorum Veterum Fragmenta (Vol. II, No.71). Teubner. (Original Work Published 1903-1905).

Arnim, V. H. (1964g). Stoicorum Veterum Fragmenta (Vol. II, No. 76). Teubner. (Original Work Published 1903-1905).

Arnim, V. H. (1964h). Stoicorum Veterum Fragmenta (Vol. II, No. 78). Teubner. (Original Work Published 1903-1905).

Arnim, V. H. (1964i). Stoicorum Veterum Fragmenta (Vol. II, No. 860). Teubner. (Original Work Published 1903-1905).

Arnim, V. H. (1964j). Stoicorum Veterum Fragmenta (Vol. II, No. 879). Teubner. (Original Work Published 1903-1905).

Arnim, V. H. (1964k). Stoicorum Veterum Fragmenta (Vol. II, No. 861, No. 866). Teubner. (Original Work Published 1903-1905).

Arnim, V. H. (19641). Stoicorum Veterum Fragmenta (Vol. II, No. 879). Teubner. (Original Work Published 1903-1905).

Arnim, V. H. (1964m). Stoicorum Veterum Fragmenta (Vol. II, No. 83, No. 863-871). Teubner. (Original Work Published 1903-1905).

Arnim, V. H. (1964n). Stoicorum Veterum Fragmenta (Vol. I, No. 202, Vol. II No. 894, Vol. III, No. 306, No.459). Teubner. (Original Work Published 1903-1905).

Arnim, V. H. (1964o). Stoicorum Veterum Fragmenta (Vol. II, No. 885). Teubner. (Original Work Published 1903-1905).

Arnim, V. H. (1964p). Stoicorum Veterum Fragmenta (Vol. I, No. 205). Teubner. (Original Work Published 1903-1905).

Arnim, V. H. (1964q). Stoicorum Veterum Fragmenta (Vol. I, No. 208). Teubner. (Original Work Published 1903-1905).

Arnim, V. H. (1964r). Stoicorum Veterum Fragmenta (Vol. III, No. 456, No. 381). Teubner. (Original Work Published 1903-1905).

Arnim, V. H. (1964s). Stoicorum Veterum Fragmenta (Vol. III, No. 459). Teubner. (Original Work Published 1903-1905).

Arnim, V. H. (1964t). Stoicorum Veterum Fragmenta (Vol. III, No.461). Teubner. (Original Work Published 1903-1905).

Becker-Carus, C. (2004). Allgemeine Psychologie: Eine Einführung. Spektrum Akademischer Verlag.

Bréhier, É. (1951). Chrysippe et l'Ancien Stoïcisme (2nd ed.). Presses universitaires de France.

Brennan, T. (2005). The Stoic Life: Emotions, Duty, Fate. Oxford University Press. 
https://doi.org/10.1093/0199256268.001.0001

Chiesa, M. (1991). Le problème du langage intérieur chez les stoïciens. Revue Internationale de Philosophie, 45, 301-321. http://www.jstor.org/stable/23949539

Cicero, M. T. (1970). Academica Posteriora: Liber Primus. M. Ruch (Ed.), Presses Universitaires de France. (Original Work Published ca. 45 BCE).

Cicero, M. T. (1994). De Officiis (pp. 1, 101, 87). M. Winterbottom (Ed.), Oxford University Press. (Original Work Published ca. 45 BCE).

Cicero. (1998). De finibus bonorum et malorum: libri quinque (Book III, p. 35). L. D. Reynolds (Ed.), Oxford University Press. (Original Work Published ca. 45 BCE).

Clement (1985). Stromata, Buch I-VI (Book II, 129, 4). O. Stählin, L. Früchtel, \& U. Treu (Eds.), Akademie-Verlag. (Original Work Published ca. 198-203 AD).

Diels, H., \& Kranz, W. (1952). Die Fragmente der Vorsokratiker: Griechisch und deutsch (II, B64). Weidmann.

Diogenes, L. (1828). De vitis, dogmatis et apophthegmatis clarorum philosophorum, libri decem. H. G. Hubner, \& A. Traversari (Eds.), C.F. Koehlerus. (Original Work Published ca. 222-235 AD).

Diogenes, L. (1999a). Diogenis Laertii Vitae Philosophorum (Vol. 1, Book VII, p. 159). M. Marcovich, \& H. Gärtner (Eds.), Teubner. (Original Work Published ca. 222-235 AD).

Diogenes, L. (1999b). Diogenis Laertii Vitae Philosophorum (Vol. 1, Book VII, p. 179). M. Marcovich, \& H. Gärtner (Eds.), Teubner. (Original Work Published ca. 222-235 $\mathrm{AD})$.

Diogenes, L. (1999c). Diogenis Laertii Vitae Philosophorum. (Vol. 1, Book VII, p. 184). M. Marcovich, \& H. Gärtner (Eds.), Teubner. (Original Work Published ca. 222-235 $\mathrm{AD})$.

Diogenes, L. (1999d). Diogenis Laertii Vitae Philosophorum (Vol. 1, Book VII, p. 85). M. Marcovich, \& H. Gärtner (Eds.), Teubner. (Original Work Published ca. 222-235 AD).

Diogenes, L. (1999e). Diogenis Laertii Vitae Philosophorum (Vol. 1: Book VII, 52, p. 53). M. Marcovich, \& H. Gärtner (Eds.), Teubner. (Original Work Published ca. 222-235 $\mathrm{AD})$.

Diogenes, L. (1999f). Diogenis Laertii Vitae Philosophorum (Vol. 1: Book VII, p. 110). M. Marcovich, \& H. Gärtner (Eds.), Teubner. (Original Work Published ca. 222-235 AD).

Diogenes, L. (1999g). Diogenis Laertii Vitae Philosophorum (Vol. 1: Book VII, p. 111). M. Marcovich, \& H. Gärtner (Eds.), Teubner. (Original Work Published ca. 222-235 AD).

Epictetus (1916a). Epicteti Dissertationes ab Arriano Digestae (Vol. III, 2, 3-4, p. 239). H. Schenkl, \& J. Schweighäuser (Eds.), Teubner. (Original Work Published ca. 104-107 $\mathrm{AD})$.

Epictetus (1916b). Epicteti Dissertationes ab Arriano Digestae (Vol. III, 23, 30, p. 320). H. Schenkl, \& J. Schweighäuser (Eds.), Teubner. (Original Work Published ca. 104-107 $\mathrm{AD})$.

Forschner, M. (1981). Die Stoische Ethik: Über den Zusammenhang von Natur, Sprach und Moralphilosophie im altstoischen System. Klett-Cotta.

Fritz, V. K. (1972). Zenon 1-5. In Pauly-Wissowa (Ed.), Realencyclopädie der Classischen Altertumswissenschaft (RE) (Vol. XA, pp. 53-138). J.B. Metzler.

Galen (1981). On the Doctrines of Hippocrates and Plato (5, 1). P. De Lacy Ed. and Trans, Akademie Verlag. (Original Work Published ca. 160 AD).

Goethe, J. W. (1808). Faust: Eine Tragödie (Verses 3456-3457). Cotta.

Gourinat, J. B. (1999). Les stö̈ciens et l'âme. K. Petropoulos Trans, A. Kardamitsas Book 
Institute. (Original Work Published 1996).

Gourinat, J.B. (2012). Les polémiques sur la perception entre stoïciens et académiciens. Philosophie antique, 12, 43-88. https://doi.org/10.4000/philosant.932

Graeser, A. (1975). Zenon von Kition. De Gruyter. https://doi.org/10.1515/9783110832228

Graver, M. (2007). Stoicism and Emotion. University of Chicago Press. https://doi.org/10.7208/chicago/9780226305202.001.0001

Ierodiakonou, K. (2015). How Feasible Is the Stoic Conception of Eudaimonia? In $\varnothing$. Rabbås, E. K. Emilsson, H. Fossheim, \& M. Tuominen (Eds.), The Quest for the Good Life (pp. 183-196). Oxford University Press. https://doi.org/10.1093/acprof:oso/9780198746980.003.0010

Kostara, S. G. (2013). Topics of Communication Psychology: Body Language. Parousia: Epitheorisi Logou kai Technis, 2, 18-35.

Krämer, H. J. (1971). Platonismus und hellenistische Philosophie. De Gruyter. https://doi.org/10.1515/9783110843170

Lesky, A. (2001). Geschichte der Griechischen Literatur (8th ed., pp. 927). A. Tsopanakis, Trans, Kyriakidis Bros SA. (Original Work Published 1957).

Long, A. A. (1982). Soul and Body in Stoicism. Phronesis, 27, 34-57. http://www.jstor.org/stable/4182138 https://doi.org/10.1163/156852882X00032

Long, A. A. (1986). Stoicism. In A. A. Long (Ed.), Hellenistic Philosophy: Stoics, Epicureans, Sceptics (2nd ed.). University of California Press.

Long, A. A. (2002). Epictetus: A Stoic and Socratic Guide to Life (pp. 207-230). Oxford University Press. https://doi.org/10.1093/0199245568.001.0001

Plutarch (1925a). On the Opinions of the Philosophers. In Plutarch (Ed.), Plutarchi Moralia (Vol. IV II, p. 1). Teubner. (Original Work Published ca. 90 AD).

Plutarch (1925b). De Stoicorum repugnantiis. In Plutarch (Ed.), Plutarchi Moralia (Vol. XI, p. 4). Teubner. (Original Work Published ca. 90 AD).

Porphyry. (1969). Pros Markellan (pp. 3-6). W. Potscher (Ed.), E.J. Brill. (Original Work Published ca. 300 AD).

Rist, J. M. (1969). Stoic Philosophy. Cambridge University Press.

Robertson, D. (2016). The Stoic Influence on Modern Psychotherapy. In J. Sellars (Ed.), The Routledge Handbook of the Stoic Tradition (pp. 394-408). Routledge. https://doi.org/10.4324/9781315771588-39

Sandbach, F. H. (1975). The Stoics. Chatto \& Windus.

Schink, W. (1913). Kant und die stoische Ethik. Kant-Studien, 18, 419-475. https://doi.org/10.1515/kant.1913.18.1-3.419

Schubert, A. (1993). Die Stoischen Vorstellungen. In K. Döring, \& T. Ebert (Eds.), Dialektiker und Stoiker. Zur Logik der Stoa und ihrer Vorläufer (pp. 271-289). F. Steiner.

Sedley, D. (1993). Chrysippus on Psychophysical Causality. In J. Brunschwig, \& M. Nussbaum (Eds.), Passions and Perceptions: Studies in Hellenistic Philosophy of Mind (pp. 313-331). Cambridge University Press.

Stein, L. (1886). Die Psychologie der Stoa. Calvary.

Stobaeus, I. (1884-1912). Ioannis Stobaei Anthologium (p. 132). C. Wachsmuth, \& O. Hense (Eds.), Apud Weidmannos. (Original Work Published ca. 5th century AD). 


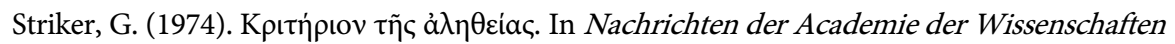
in Göttingen (pp. 48-110). Vandenhoeck \& Ruprecht.

Turner, M. J., Wood, A. G., Boatwright, D., Chadha, N., Jones, J. K. \& Richard, B. (2021). Assessing Beliefs about Emotion Generation and Change: The Conceptualisation, Development, and Validation of the Cognitive Mediation Beliefs Questionnaire (CMBQ). Psychotherapy Research, 31, 932-949. https://doi.org/10.1080/10503307.2020.1871524 